\title{
THE GREAT RECESSION INSIDE THE BELTWAY: EVIDENCE FROM INTERVIEWS WITH BUSINESS LEADERS
}

DOI: 10.17261/Pressacademia.2018.831

RJBM- V.5-ISS.2-2018(4)-p.121-129

\author{
Rebecca H. Padot \\ Misericordia University, Pennsylvania, USA. \\ rkowal@sas.upenn.edu, ORCID: 0000-0002-4704-4938
}

To cite this document:

Padot, R. H. (2018). The great recession inside the beltway: Evidence from interviews with business leaders. Research Journal of Business and Management (RJBM), V.5(2), p.121-129.

Permanent link to this document: $\mathrm{http}: / /$ doi.org/10.17261/Pressacademia.2018.831

Copyright: Published by PressAcademia and limited licenced re-use rights only.

\begin{abstract}
Purpose- The goal of this study was to understand how the economic climate during the United States Great Recession affected businesses in the heart of the recession.

Methodology - Fifteen interviews with CEOs, Presidents, and Founders from the Capital Region were conducted in order to determine how businesses were affected during this time period. These leaders represented companies which ranged in size from new start-ups to established small businesses to hundred-million dollar plus companies.

Findings- The data suggests that economic repercussions from the Great Recession was not distributed evenly among businesses in this region. A pattern emerged that showed that two general types of companies felt the repercussions differently. Companies selling predominantly to the private sector navigated the financial crisis by being focused on cost-reduction of either their own operating costs or of their products and services delivered to their clients. Whereas, companies selling predominantly to the federal government were largely insulated from the Great Recession.

Conclusion- The findings suggest practical implications for business growth include cost-reduction of operations, price reductions on their products and services, and expansion into the federal public sector. Rather than looking at economic downturns as a negative for the small business, small businesses can creatively outmaneuver these downturns with the aforementioned methods.
\end{abstract}

Keywords: Great recession, US economy, strategy, business growth, CEOs

JEL Codes: E32, L26, P12

\section{INTRODUCTION}

The National Bureau of Economic Research dates the United States Great Recession from December 2007 to June 2009 and recognized that this 18 month recession is the longest of any recession since World War II (National, 2010). Job losses, home foreclosures, and decimation of some retirement portfolios became personal casualties (Stiglitz, 2012). Yet for businesses, the Great Recession created uncertainty (Cynamon, et. al, 2014; Reinhart \& Rogoff, 2009; Bloom, 2014; Paulson, 2010), a decrease in the ability to obtain financing (Reaser, 2011), tumultuousness surrounding a customer base (Tamminen, 2017; Sheffi, 2015), increased risk of going out of business (Geithner, 2014; Aliber \& Kindleberger, 2015), and unknowns about government policy intervention (Paulson, 2010; Geithner 2014).

This crisis also alerted people to the extent that government and business are interconnected. Government affects business when it makes decisions on interest rates, regulation, government contracting, lending, and countless other policies. In fact, companies such as General Motors relied on government support to such an extent that The Motley Fool and other media would refer to them as "Government Motors" (Rosevear, 2013). Business affects government when policies, such as The Troubled Asset Relief Program, are needed in response to business failures.

The United States Great Recession offers a great opportunity to examine how businesses fared during this time period in order to help small businesses prepare now for future economic downturns. Heading right to the heart of significant government and business activity during the U.S. Great Recession, this paper offers original data from 15 CEO/President/Founder interviews from the Washington, D.C. Capital region. The interviews represent leaders at new 
start-ups, established small businesses, and hundred-million plus dollar companies. The research question this article examines is how did the economic climate during the United States Great Recession affect businesses in our nation's capital? The results from the findings will offer businesses an action plan to implement now in order to limit their downside during future economic instability.

In the following section, I present the theoretical background regarding the depth of the financial crisis and its' effect on businesses, followed by the data collection and methods in the third section. The fourth section offers findings concerning the business practices that led to success, followed by implications and conclusions with actionable steps for small businesses.

\section{LITERATURE REVIEW}

\section{Depth of the Financial Crisis}

The United States Great Recession had a major impact on the United States economy and the depth of the crisis was alarming. Recognized as a severe financial crisis, "The Great Recession created the most severe disruption of the U.S. economic activity since the 1930s" (Cynamon, et. al, 2014, p. 6.) Economists Reinhart and Rogoff noted that the "global financial crisis of the late 2000s, whether measured by the depth, breath, and (potential) duration of the accompanying recession or by its profound effect on asset markets, stands as the most serious global financial crisis since the Great Depression" (2009, p. 208). This recession affected individuals so severely that Nobel Prize Winner Joseph Stiglitz wrote "The Great Recession thus represented a triple whammy for many Americans: their jobs, their retirement incomes, and their homes were all at risk" $(2012$, p. 13)

Both U.S. Treasury Secretaries who navigated the United States through the financial crisis and the aftermath were vivid in their assessment of how turbulent the economy was for all parties involved, such as, citizens, businesses, government and international partners.

U.S. Treasury Secretary Henry M. Paulson Jr., who led treasury at the time of the crisis from July 2006 until January 2009, made comments such as, "Throughout the fall of 2007, the markets remained tight and unpredictable" (2010, p. 77), referring to fall 2007 in that "the bad news piled up day by day" (2010, p. 83), and finally after Lehman Brothers filed bankruptcy in 2008, "I wondered if anyone out there on the streets could possibly imagine what was about to hit them" (2010, p. 222). He added "Between March and September 2008, eight major U.S. financial institutions failed - Bear Stearns, IndyMac, Fannie Mae, Freddie Mac, Lehman Brothers, AIG, Washington Mutual, and Wachovia - six of them in September alone" (2010, p. 436). By Fall 2008, Paulson recalled, "All financial companies were under pressure, but [Citigroup] was being hammered the hardest" (2010, p. 403). By December 1, 2008, Paulson recollected, ". . . the markets turned ugly again, as the National Bureau of Economic Research announced that the U.S. was officially in a recession and had been for the past year. The Dow plunged 680 points, or 7.7 percent ..." (2010, p. 421).

Following Paulson's term in office, U.S. Treasury Secretary Timothy Geithner replaced him while the recession was in progress. To summarize Geithner's initial job start, he noted:

On the morning of January 27, 2009, my first full day as secretary of the Treasury, I met with President Barack Obama in the Oval Office. The worst financial crisis since the Great Depression was still raging, and he wanted to put out the fire for good. The banking system was broken. The broader economy was contracting at a Depression-level rate (Geithner, 2014, p. 1).

In The New York Times op-ed in August 2010, Geithner added, "The recession that began in late 2007 was extraordinarily severe ..." (August 2, 2010). The Great Recession rippled through the U.S. economy and left substantial carnage.

\section{The Financial Crisis' Effect on Business}

There was wide recognition that the Great Recession also affected businesses. Lynn Reaser, in the National Association for Business Economics Presidential Address, noted "The 'Great Recession' pummeled small businesses as sales nosedived and credit tightened. Aspiring entrepreneurs saw venture and other sources of start-up capital largely vanish" (Reaser, 2011, p. 21). Mishkin offered, "The general rise in uncertainty that occurs during a financial crisis also leads to an increase in asymmetric information, further hindering the ability of financial markets to allocate funds to households and businesses with productive investment opportunities" (2011, pp. 57-58).

Princeton economist Atif Mian and University of Chicago Finance Professor Amir Sufi noted that "large increases in household debt and economic disasters seem to be linked to collapses in spending" (2014, p. 9). Disagreeing with their premise for the cause of the financial crisis, Poole noted that "financial firms were vulnerable to crisis because of excessive leverage" (Poole, 2009, p. 40). 
In addition, the effects of the Great Recession were felt throughout the finance sectors, "Nearly three hundred mortgage banking firms failed. Nearly five hundred commercial banks were closed by the Federal Deposit Insurance Corporation" (Aliber and Kindleberger, 2015, p. 336). Further, "Job losses in late 2008 reached their highest levels since the 1930s, and the stock market tumbled" and "The Dow Jones Industrial Average lost more than 50 percent of its value between 2007 and 2009" (Conlan and Posner, Economic, p. 20-21).

Sorkin noted that "[Secretary] Paulson told Bush in no uncertain terms that the financial system was collapsing. 'If we don't act boldly, Mr. President,' he said, 'we could be in a depression deeper than the Great Depression,' an assessment with which [Chairman of the Federal Reserve] Bernanke concurred" (Sorkin, 2009 p. 440).

This downturn in business due to the Great Recession was also felt beyond the United States: "Global exports of goods decreased by 22 per cent from 2008-2009 (based on the United Nations Statistics, UN Comtrade database, World exports of goods in total 2008 - 2009) and the financial system was severely hit in many countries" (Tamminen, 2017, p. 33).

Businesses responded to the financial crisis with cost-cutting. Yossi Sheffi noted that '“Hunkering down' for survival was the prevailing behavior of customers, suppliers, and companies in many industries. Responding to falling orders from their customers, companies cut orders to their suppliers even further, thus contributing to the bullwhip" (2015, p. 113). This created an era of uncertainty for businesses navigating the financial crisis in that they were unsure of whether to hire and where to invest during the Great Recession (Bloom, 2014, p. 153). The next section delves into the experiences of 15 companies in the Great Recession.

\section{DATA AND METHODOLOGY}

I conducted 15 prearranged interviews with CEOs/Presidents/Founders (henceforth, CEOs) from the Capital Region. The companies ranged in size from new start-ups, such as Green Paper Studio to established small businesses like BoxTone to hundred-million plus dollar companies like Intelsat General. The full list of interviewees can be accessed via Appendix A.

The National Bureau of Economic Research dates the United States Great Recession between December 2007 and June 2009 and recognized that this makes the 18 month recession the longest of any recession since World War II (National Bureau, 2010). I utilized this time period as guidance for interview completion as all interviews were conducted during the United States Great Recession or within six months thereafter.

Interviewees were selected after showing a pattern of success in their business sector in the Washington, DC region, which encompasses Baltimore and Northern Virginia. Interviews were requested via e-mail and phone, were conducted in person in the Washington, DC region, and ranged from 10 minutes to 35 minutes. Each interview was recorded in full and was also made publicly available with no edits shortly after completion (Leaders Portfolio, 2018). Interviewees were provided no remuneration and all interviews were publicly visible. For every one completed interview approximately two additional were requested and the primary turndown reason was regarding the interviewee not being available on the select few dates provided by the interviewer.

The content of each interview covered the CEO's background, their company, their leadership philosophy, and the economic climate. Additional questions remained open-ended. According to methodologist, Robert Yin, "most commonly, case study interviews are of an open-ended nature, in which you can ask key respondents for the facts of a matter as well as for the respondents' opinions about events" (Yin, 1994). These interviews followed that rationale in that each interview was open ended and centered on the interviewee's area of expertise. There was no universal discussion guide for all interviewees as the type of interviewee and their involvement with their companies ranged substantially.

Information is provided here that offers background on the interviewer's capability. In the last two and a half decades, I have conducted over 3,000 elite interviews for major market media outlets and/or academic purposes. Because this number of elite interview completions is high for a qualitative social scientist, this expertise should minimize some of the concerns that might be associated with interviews conducted for case research.

\section{FINDINGS: PRIVATE SECTOR CLIENTS VERSUS FEDERAL PUBLIC SECTOR CLIENTS}

As previously mentioned, I interviewed 15 company CEOs during the height and immediate aftermath of the Great Recession. From the interview sample, there were 4 companies that sold mainly to the federal government and 11 companies that largely sold to the private sector.

The federal government was still spending significant money on contractors during the Great Recession, while the private sector was retracting from spending. For this reason, the interviews are categorized below distinctly as companies that sell to the private sector and, secondly, companies that sell to the federal government. I did not set out to interview an equal sample size from both of those sets of companies, however, the findings suggested the interviewees could be grouped according to those two categories. 


\section{Companies that Sell to the Private Sector}

Companies that stated a main objective was to sell a product or service to the private sector are included here in this section.

Ted Leonsis, Owner of the NHL's Washington Capitals, said "Our goal is to build a generationally great team that can win a Stanley Cup and let's trade all of our old guys who are brand names and rebuild the team" (Leonsis, 2008). He went on to add, "We won the division and this year we are picked as a really great team and our business has never been stronger and the fan base satisfaction is really, really high" (Leonsis, 2008). Recognizing that not all businesses are surviving in this era and drawing on the knowledge from his major media executive background, he also noted that "print-based media companies are shrinking, l'd say in danger right now" (Leonsis, 2008).

Dr. Steve Armentrout, Founder and CEO of Parabon Computation, said "It's very easy to get caught up in the current economic situation" (Armentrout, 2009). Recognizing that his software company helps businesses save money, Dr. Armentrout said "So the way we're approaching this is actually fairly aggressively. Whereas a lot of companies are pulling back, we're touching more and more potential customers because the message is resonating" (Armentrout, 2009).

SpaceNet CEO Andreas Georghiou provides satellite solutions for the private sector, as well as the public sector. Noting that the private sector side was hit hard, he said:

Obviously a lot of our big enterprise customers have a need for conserving cash and so any decisions to deploy our equipment and then a contract for one's service either gets delayed or postponed, and that has a very direct impact on our operations. It turns out in 2008 we had our best year in the history of SpaceNet. But 2009 is not shaping up nearly as good but the way we try to respond to that besides cost controlling and all of that is to see if we find ways to lessen the cash flow impact up front for customers (Georghiou, 2009).

Alan Snyder, CEO of BoxTone, a mobility company, believes the downturn in the economy that has focused on cost reduction has actually helped his business. Snyder noted:

... A large part of what we do is offer the ability for customers to use mobility but do it at a lower cost. And so that actually, what we found is, sure there are some customers that because of economic conditions, don't have the funds they once had to go spend money at BoxTone. But there's a whole new set of customers that previously they had plenty of cash and so they were applying bodies instead of automation to make mobility run better. So we've actually seen new business come in. So when you look at BoxTone we had a record quarter, last quarter. We grew $70 \%$ over our second quarter. We grew $50 \%$ over third quarter last year. So it's actually worked out very, very well for us because of the value proposition and because of the breadth of the product that we have (Snyder, 2009).

Stanislas Vilgrain, President and CEO of Cuisine Solutions, a company that provides fully cooked and prepared foods to the private sector, as well as, the military, noted that "our customers [including casual dining chains and hotel chains] have been hit pretty hard." Since the company focuses on reducing the size of the kitchen imprint for casual dining operators, the company in effect can save their client money. Vilgrain said:

We can have those [meals] done and not prepared, but they assemble it at a restaurant. It can deliver, I believe, better quality food, safer, much more the right ingredients, organic, lower calories, but very tasty food for a fraction of the cost that they use to deliver that. So I think for us, it's actually. . . the recession is actually helping us. People have to change the way they view their restaurant business (Vilgrain, 2009).

E. Hunt Burke, CEO and Vice Chairman of the Board, Burke and Herbert, the oldest continually operating bank in the Washington DC area which provides personal and business banking, said:

There are a lot of people that are struggling. There's a lot of retail. There's a lot of unemployment still. . . People's stock portfolios are going to be a long time coming back, so there are a lot of businesses that are still struggling day to day, trying to make it (Burke, 2009).

Regarding Burke's approach to the recession, he said:

We've been through some recessions in the past and we found that working with people is far preferable to pulling the rug out from under them. So you do that, you pull the rug out from under somebody and you're in a down real-estate market and your collateral may be impaired so there's really no reason to play hard ball when you can finesse your way. . . And then you've got a customer for life, if not for generations (Burke, 2009). 
James Weaver, President, W.T. Weaver and Sons, who has worked for 54 years at his family's Georgetown hardware store, said that the economic climate:

It's the worst l've ever seen. And the recovery, we feel it, is taking effect right now. And you're seeing, I think one of the disheartening things, you have bid so much at this point and if you want to do the work you're going to have to either honor or compromise your bid. . .(Weaver, 2009).

Weaver, whose company has furnished the presidential White House, added that "the people who have the money I think are just hesitant at this point as to what they will do with it" (Weaver, 2009).

Kris Appel is the Founder and President of Encore Path which is a small business just starting out that provides medical devices for stroke survivors. She first stated, "People have strokes and people need rehabilitation, that's not changing because of the economic situation" (Appel, 2009). But then added that due to the economic situation, ". . I've gotten some really tremendously talented people to come work in the company because they were laid off or because they wanted something a little more rewarding" (Appel, 2009).

Tracy Bloom Schwartz, the President of Green Paper Studio, an ecofriendly paper manufacturer, noted "that over the last two years it's been a very challenging place. . . So being in a discretionary industry, we've definitely seen a drop. . . We've definitely seen the entire industry fall 20\%" (Bloom Schwartz, 2009).

Alvin Thompson, New Couture, Owner, of a couture dress shop, noted that the economy has resulted in the following, "I would say the client wants to know that there's value for the money [they spend]" (Thompson, 2009).

Steelcloud is a public company, which is a developer and manufacturer of compliance based technology solutions for both the public and private sectors. Since the company also sells to the private sector, Brian Hajost, President and CEO of Steelcloud, noted that "Steelcloud much like many companies was affected by the economy. I was brought back in to raise money and refocus the company on those areas that were going to provide our shareowners the most value" (Hajost, 2009).

In sum, these leaders of companies that largely serve the private sector commonly referred to the economic climate or the cost-cutting responses they have taken to maintain clients. These were the types of aforementioned comments associated with leaders selling to the private government: SpaceNet: "besides cost controlling . . . lessen the cash flow impact up front for customers;" BoxTone: "we . . . offer the ability for customers to use mobility but do it at a lower cost;" Burke and Herbert: "we found that working with people is far preferable to pulling the rug out from under them;" Cuisine Solutions: "tasty food for a fraction of the cost;" New Couture: "the client wants to know that there's value for the money;" and finally, W.T. Weaver and Sons: "And the recovery. . . we feel it."

These company leaders spoke frequently about the impact of the Great Recession and the aftermath. The trend of the comments suggested the leaders' were aware their customers were facing pain, that their own companies needed to reduce the cost of products and services, or that they needed to sell a financially frugal product or service. The finding here is that companies selling predominantly to the private sector navigated the financial crisis by being focused on costreduction of either their own operating costs or of their products and services delivered to their clients.

However, this finding did not apply to all companies in this section, but rather was a consistent theme during most interviews. Three companies that serve the private sector were exceptions to this trend. Interviewee data from NHL's Washington Capitals, which was valued at more than its purchase price by $2008,{ }^{1}$ did not follow this trend. This was probably due to the fact that many high-valued sports franchises are generally profitable no matter the economic cycle. As new businesses, Encore Path and Green Paper Studio recognized the significant impact the depressed economy was making on their businesses, but also did not follow the aforementioned trend. Encore Path, created three years earlier, ${ }^{2}$ relied on grants for funding and, therefore, was not fully dependent on generating revenue yet on their own. So it is hard to know whether they would have followed the trend of the other businesses selling to the private sector.

Green Paper Studio was also a very new business that had been launched approximately 20 months prior to our interview. However, the business likely had trouble getting off the ground. As of current, the website of Green Paper Studio was no

\footnotetext{
${ }^{1}$ NHL Team Valuations

\#30 Washington Capitals, Forbes,

11.09.06, https://www.forbes.com/lists/2006/31/biz_06nhl_Washington-Capitals_312495.html And Statista, Washington Capitals Franchise Value from 2006 to 2017, https://www.statista.com/statistics/194994/nhl-franchise-value-of-the-washington-capitals-since2006/ Accessed 4.3.18

${ }^{2}$ Leaders Portfolio, Encore Path, October 28, 2009. http://leadersportfolio.com/archives/1406 Accessed 4.9.18
} 
longer active and all visible signs have pointed to the eventual closure of the business. ${ }^{3}$ So the possibility exists that Green Paper Studio did not follow the above cost-cutting trends followed by their peers that sell to the private sector and this may have resulted in the eventual closure of their business.

\section{Companies that Sell to the Federal Government}

Companies that stated a main objective was to sell a product or service to the federal government are included here in this section.

Omniplex World Services Corporation is a private company with about 2700 federal investigators whose "clients are primarily the federal government" stated Julien Patterson, Founder and CEO of Omniplex World Services Corporation (Patterson, 2008). With approximately $\$ 115$ million in revenues, Omniplex has "two separate companies with support structure and centralized services to each. And both are doing amazingly well in this economy" (Patterson, 2008).

Chris D'Agostino is the CEO of Near Infinity which is a multi-million dollar software development company whose main customer is the federal government. Referring to the Washington DC Region, he noted "The economy here is slightly insulated from the broader economy throughout the United States ..." (D'Agostino, 2009). Like Omniplex, Near Infinity's leadership recognizes the value of the federal government to the bolstering of the company's bottom line.

Intelsat General is a provider of fixed and mobile commercial satellite services for the government including the U.S. Department of Defense, the U.S. Department of State, and the U.S. Department of Homeland Security. Kay Sears, President, Intelsat General, noted that her number one responsibility is:

Setting a clear and compelling direction. Getting everybody on the same page, getting buy in from your senior team, getting buy in from the corporation that this is the strategy...making sure we're on track . . f for 2009 and beyond to be as successful as we were in 2008 (Sears, 2008).

To recap, Intelsat General's leadership mentioned the financial success they were having in 2008 which was in the midst of the Great Recession.

There is also a recognition that the government is pouring money into federal contractors during the great recession. Michael Tinsley, President and CEO of NeoSystems, a government contractor that provides accounting software solutions, said:

Where there has been growth even in a down economy, the government with coming out with the stimulus package to help stimulate the economy, a fair amount of spending will actually find its way into the economy through government contracting firms (Tinsley, 2009).

With that being said, Tinsley did face a challenge in obtaining financing from the private sector. He struggled to obtain financing for his business during the Great Recession before obtaining \$5 million for expansion, and said "It is difficult for us just as it is for any company right now to secure financing" (Tinsley, 2009).

In sum, these leaders selling to the federal government utilized terms that described how well their company or the economy was doing while in the midst of the Great Recession. These were the types of aforementioned comments associated with leaders selling to the federal government: Omniplex: "amazingly well in this economy;" IntelSat General: "making sure we're on track . . . for 2009 and beyond to be as successful as we were in 2008;" Near Infinity: "the economy here is slightly insulated from the broader economy throughout the United States;" and finally, NeoSystems: "a fair amount of spending will actually find its way into the economy through government contracting firms."

Their experience in the midst of the Great Recession and the aftermath was entirely different than those selling primarily to the private sector. The finding here is that companies selling predominantly to the federal government were largely insulated from the Great Recession. A word of caution here is that the sample size for this finding was very small and included a total of four companies. For that reason, it would be wise to take this finding as a preliminary finding that should be corroborated with follow-up research utilizing a greater sample size.

\section{IMPLICATIONS and CONCLUSION}

Although I did not set out to interview company leaders and sort their companies into two categories, the findings suggested a trend for two distinct categories. This trend applied to most, but not all of the companies surveyed. The economy affected two sectors of Capital Region businesses differently. The companies serving federal government clients

\footnotetext{
${ }^{3}$ Note: The website link was inactive. No company registration existed for Green Paper Studio in Maryland (https://egov.maryland.gov/BusinessExpress/EntitySearch). Even if Green Paper Studio was assumed under the CEO's other company, Creative Parties, there was no visual presence for Green Paper Studio on the web.
} 
were largely insulated from the Great Recession and the aftermath. Whereas, companies serving the private sector navigated the financial crisis by being focused on cost-reduction of either their own operating costs or the products and services delivered to their clients. Companies such as Burke and Herbert even performed cost-cutting via non-traditional means which included cutting the customer a financial break regarding actual the valuation of their collateral.

The economic repercussions from the Great Recession was not distributed evenly among businesses. A pattern emerged that showed that two general types of companies felt the repercussions differently.

\section{Businesses Selling to the Private Sector}

The finding here is that companies selling predominantly to the private sector navigated the financial crisis by being focused on cost-reduction of either their own operating costs or of their products and services delivered to their clients.

Regarding the companies serving private sector clients, it is not surprising that during the Great Recession companies of all sizes emphasized cost cutting. However, the data showed that this cost cutting was performed via two methods. The companies either focused on cutting their own operating costs and/or via the costs of the products and services delivered to their clients. If a small business selling to the private sector were to maximize their profits in the next economic downturn, they should consider implementation of both of these two methods. Further, the businesses also implemented creative solutions for cost-reductions of the cost of products and services to their clients. One example was how SpaceNet attempted to "find ways to lessen the cash flow impact up front for customers." A second example was how E. Hunt Burke found ways to reassess the value of the impaired collateral so as not to "pull the rug out from under somebody" in order to have "a customer for life." A small business should consider creative outside-the-box cost-cutting solutions as well for the client.

\section{Businesses Selling to the Federal Government}

The finding here is that companies selling predominantly to the federal government were largely insulated from the Great Recession.

Regarding the companies serving federal government clients, it is not surprising that government would affect business as the two are often intertwined. Further, government has a crucial role in determining the economic climate from which within businesses operate. The President of the Southern Economic Association, Peter Boettke, recognized in his 2018 Presidential Address that public administration and the U.S. economy have been inextricably linked over a number of decades (2018, p. 939). However, we often think about government affecting the economic climate and policies for businesses. Yet, this research brings additional awareness that the federal government in and of itself is a customer of business and can therefore affect business outcomes in a recession by being a purchaser of their private goods.

Traditionally, there has been discussion about the federal government unleashing their public funds for infrastructure projects such as President Obama's American Recovery and Reinvestment Act (ARRA) as a mechanism to spur economic growth (Conlan, Posner and Regan, 2017, p. 1). However, these findings suggest that the federal government can also utilize public spending to private businesses (sometimes called "government-by-proxy" or "third-party government") across a range of businesses in an effort to produce better economic outcomes for businesses. Likewise, this research also suggests that in economic downturns, businesses selling to the private sector may want to buffer their cost-cutting with an expansion of their revenue share being obtained from the public sector. This data specifically showed a pattern of sales to the federal sector, but businesses may want to consider other public sectors as well (i.e. state and local).

Rather than looking at economic downturns as a negative for businesses, small businesses can creatively outmaneuver these downturns with the aforementioned methods. Stanslis Vilgrain, winner of the 2007 Ernst \& Young Entrepreneur of the Year for Greater Washington DC Area, added, "This is a recession [to] create change. I mean I've been in this country 25 years and I've never seen it as bad as this is. So what an opportunity to create change. . We have to use what's less costly" (Vilgrain, 2009). Future economic downturns are an opportunity to create change for businesses.

\section{ACKNOWLEDGEMENTS}

This research has received financial support from the following sources:

The Misericordia University Faculty Research Grant and Summer Research Grant Program.

This researcher has received financial support from the following sources:

The Earhart Foundation, The Mumford Fund, The Bradley Foundation, The Fox Leadership Program, and PRRUCS at The University of Pennsylvania. 


\section{APPENDIX A: LIST of INTERVIEWS}

Armentrout, Dr. Steve, Founder and CEO, Parabon Computation, interview, Washington, DC region, April 1, 2009.

Appel, Founder and President, Encore Path, interview, Washington, DC region, October 28, 2009.

Bloom Schwartz, Tracy, President, Green Paper Studio, Washington, DC region, November 4, 2009.

Burke, E. Hunt, CEO and Vice Chairman of the Board, Burke and Herbert, interview, Washington, DC region, October $28,2009$.

Georghiou, Andreas, CEO, SpaceNet, interview, Washington, DC region, April 15, 2009.

D’Agostino, Chris, CEO, Near Infinity, interview, Washington, DC region, May 12, 2009.

Hajost, Brian, President and CEO, Steelcloud, interview, Washington, DC region, November 11, 2009.

Leonsis, Ted, Owner, NHL's Washington Capitals; Vice Chairman Emeritus, AOL, interview, Washington, DC region, November 26, 2008.

Patterson, Julien, Founder and CEO, Omniplex World Services Corporation, interview, Washington, DC region, August 27, 2008.

Sears, Kay, President, Intelsat General, interview, Washington, DC region, December 12, 2008

Snyder, Alan, CEO, BoxTone, interview, Washington, DC region, October 18, 2009.

Thompson, Alvin, Owner, New Couture, interview, Washington, DC region, November 25, 2009.

Tinsley, Michael, President and CEO of NeoSystems, interview, Washington, DC region, interview, April 8, 2009.

Vilgrain, Stanislas, President and CEO, Cuisine Solutions, interview, Washington, DC region, October 18, 2009.

Weaver, James, President, W.T. Weaver and Sons, interview, Washington, DC region, October 28, 2009.

\section{REFERENCES}

Aliber, R. \& Charles P. Kindleberger. (2015). Manias, Panis, and Crashes: A History of Financial Crisis, $7^{\text {th }}$ ed., New York, New York: Palgrave Macmillan.

Bloom, N. (Spring 2014). Fluctuations in Uncertainty, Journal of Economic Perspectives, Vol 28, No 2, doi: 10.1257/jep.28.2.153

Boettke, Peter. (2018). Presidential Address: Economics and Public Administration, Southern Economic Journal, Vol 84, No. 4, doi: 10.1002/soej.12265.

Conlan, T. \& Posner, Paul. (2017). Economic Crisis and Policy Response: The Context, Design, and Politics of the Recovery Act. In Conlan, T. J., Posner, P. L., \& Regan, P. M., Governing Under Stress: The Implementation of Obama's Economic Stimulus Program (pp. $19 \quad-\quad 44)$. Washington, D.C.: Georgetown University Press.

Conlan, T. Posner, Paul \& Regan, P. (2017). Managing the Great Recession: A Stress Test for Modern Governance. In Conlan, T. J., Posner, P. L., \& Regan, P. M., Governing Under Stress: The Implementation of Obama's Economic Stimulus Program (pp. 1 - 18). Washington, D.C.: Georgetown University Press.

Cynamon, B.Z., Fazzari, S. M., \& Setterfield, M. (2014). Understanding the Great Recession. In Cynamon, B.Z., Fazzari, S. M., \& Setterfield, M. (Eds.), After the Great Recession: The Struggle for Economic Recovery and Growth (pp. 1- 30). New York, New York: Cambridge University Press.

Geithner, T. F. (2014). Stress Test: Reflections on the Financial Crisis, New York, New York: Crown Publishers.

Geithner, T. F. (August 2, 2010). Welcome to the Recovery, Op-Ed, The New York Times, https://www.nytimes.com/2010/08/03/opinion/03geithner.html.

Leaders Portfolio. (2007 - 2009). Retrieved from Leaders Portfolio website: www.leadersportfolio.com/audio

Mian, A. \& Amir Sufi. (2014). House of Debt: How They (And You) Caused the Great Recession, and How We Can Prevent It from Happening Again, Chicago, IL: University of Chicago Press.

Mishkin, F. S. (2011). Over the Cliff: From the Subprime to the Global Financial Crisis, Journal of Economic Perspectives, Volume 25, No. 1, doi: $10.1257 /$ jep.25.1.49.

The National Bureau of Economic Research. (September 20, 2010). Business Cycle Dating Committee, Press Release, Retrieved from http://www.nber.org/cycles/sept2010.pdf and http://www.nber.org/cycles/sept2010.html

Paulson, Jr., H. (2010). On the Brink: Inside the Race to Stop the Collapse of the Global Financial System, New York, New York: Hachette Book Group.

Poole, W., (January 2009). The Credit Crunch of 2007-2008: Lessons Private and Public, Business Economics, Volume 44, Issue 1, doi: $10.1057 /$ be. 2008.1 
Reaser, L., (2011). The "New Economic Reality": How New and How Real? Business Economics, Volume 46, Issue 17, doi: 10.1057/be.2010.37.

Reinhart, C. M. \& Rogoff, K. S., (2009). This Time is Different: Eight Centuries of Financial Folly, Princeton, NJ: Princeton University Press.

Rosevear, J., (March 23, 2013). Why 'Government Motors' Still Owes You, The Motley Fool, http://www.fool.com/investing/general/2013/03/23/why-government-motors-still-owes-you.aspx

Sheffi, Yossi., (2015). The Power of Resilience, Cambridge, MA: MIT Press.

Sorkin, A. R., (2009). Too Big To Fail, New York, New York: Penguin.

Stigliz, J., (2012). The Price of Inequality: How Today's Divided Society Endangers Our Future, New York, New York: W.W. Norton \& Company.

Tamminen, S., (2017). Regional effects or none? Firms' profitability during the Great Recession in Finland, Papers in Regional Science, Volume 96, Number 1, doi: 10.1111/pirs.12222.

The National Bureau of Economic Research. Business Cycle Dating Committee, Press Release September 20, 2010. http://www.nber.org/cycles/sept2010.pdf and http://www.nber.org/cycles/sept2010.html

Yin, R. Case Study Research: Design and Methods, 2nd Ed. Applied Social Research Methods Series, Vol. 5. Thousand Oaks, CA: SAGE Publications, 1994. 